Article

\title{
Using Small Capacity Fuel Cells Onboard Drones for Battery Cooling: An Experimental Study
}

\author{
Shayok Mukhopadhyay *, Sheehan Fernandes, Mohammad Shihab and Danial Waleed \\ Department of Electrical Engineering, American University of Sharjah, Sharjah P.O. Box 26666, UAE; \\ b00049935@aus.edu (S.F.); b00048715@aus.edu (M.S.); b00050113@aus.edu (D.W.) \\ * Correspondence: smukhopadhyay@aus.edu; Tel.: +971-06-515-2651
}

Received: 29 April 2018; Accepted: 4 June 2018; Published: 6 June 2018

\begin{abstract}
Recently, quadrotor-based drones have attracted a lot of attention because of their versatility, which makes them an ideal medium for a variety of applications, e.g., personal photography, surveillance, and the delivery of lightweight packages. The flight duration of a drone is limited by its battery capacity. Increasing the payload capacity of a drone requires more current to be supplied by the battery onboard a drone. Elevated currents through a Li-ion battery can increase the battery temperature, thus posing a significant risk of fire or explosion. Li-ion batteries are suited for drone applications, due to their high energy density. There have been attempts to use hydrogen fuel cells onboard drones. Fuel cell stacks and fuel tank assemblies can have a high energy to weight ratio. So, they may be able to power long duration drone flights, but such fuel cell stacks and associated systems, are usually extremely expensive. Hence, this work proposes the novel use of a less expensive, low capacity, metal hydride fuel stick-powered fuel cell stack as an auxiliary power supply onboard a drone. A primary advantage of this is that the fuel sticks can be used to cool the batteries, and a side effect is that this slightly reduces the burden on the onboard Li-ion battery and provides a small increment in flight time. This work presents the results of an experimental study which shows the primary effect (i.e., decrease in battery temperature) and the secondary side effect (i.e., a small increment in flight time) obtained by using a fuel cell stack. In this work, a metal hydride fuel stick powered hydrogen fuel cell is used along with a Li-ion battery onboard a drone.
\end{abstract}

Keywords: drone; battery; cooling; fuel cell

\section{Introduction}

Numerous applications can potentially benefit from the use of drones. This has attracted a lot of research related to drones. Drone based delivery services continue to fascinate us. Such a drone based delivery service is already in use for the delivery of medical supplies [1]. There has been some work related to completing autonomous drone delivery missions when there is communication failure [2]. Researchers have also worked with drone delivery scheduling [3], battery charging issues, battery assignment [4], routing issues [5] and also a surveillance network [6] for delivery drones.

However, as pointed out in [5], the problem of routing delivery drones is not trivial, because several issues, like flight distance, power usage, and payload weight, need to be considered. Because of their high energy density [7], Li-ion batteries are a natural choice for use onboard drones. However, drone flight times still continue to be short, because of the high current required for flying. A high current discharge from a battery can increase its temperature [8]. An increased battery temperature can lead to a decrease in battery life. Further, if the temperature of a Li-ion battery reaches around $60{ }^{\circ} \mathrm{C}$, then there is a risk of thermal runaway, which may lead to an explosion and fire [8]. Motivated by the need to combat such issues, researchers have developed models and techniques for predicting battery behavior [9-17]. Methods to determine parameters of a thermal model of a Li-ion 
battery were reviewed in [9]. The authors in [10] combined impedance-based and electrochemical techniques to examine the thermal effects on charging a battery. Fast thermal runaway detection was addressed in [11]. Battery models that focus on thermal behavior were described in [12-14]. Literature also exists on special techniques for Li-ion battery model parameter estimation, which can reduce the number of experiments required for estimating battery parameters [15]. Observers have also been used to estimate internal states of batteries [16]. Detecting battery terminal voltage collapse without the need of an accurate model was investigated in [17].

Instead of using models to predict battery behavior, and thus avoiding the possibility of thermal runaway due to a rise in battery temperature on account of high current loading, an alternative approach may consist of reducing the load current that needs to be supplied by a battery. This has been investigated for unmanned aerial vehicles (UAVs), and drones, by incoporating a second onboard energy source, e.g., a fuel cell. Flight times can be improved by employing fuel cells onboard drones [18]. Literature related to using fuel cells onboard UAVs exists $[19,20]$. However, the usage of fuel cells onboard large fixed wing UAVs may prove easier than on small quadrotor-based drones, because a larger vehicle has more space available to accommodate the fuel tanks required along with the fuel cell. Further, as mentioned in [18], a fuel cell system to be used on a drone needs to be sophisticated, i.e., lightweight and compact. Using such a sophisticated fuel cell system may increase flight time, and such a specialized product is usually prohibitively expensive.

Thus, this paper proposes the use of a low capacity, low cost, metal hydride fuel stick-powered fuel cell onboard a drone, in addition to a Li-ion battery pack. The low capacity metal hydride fuel stick-powered fuel cell stack was chosen because (i) it is much less expensive compared to a sophisticated aerospace grade fuel cell stack; (ii) being low capacity, it is compact and light in weight; (iii) the metal hydride fuel stick cools as it supplies the fuel required for the fuel cell stack to operate; and (iv) the low capacity fuel cell stack can act as a backup power source to keep the microcomputer and communication circuitry onboard a drone alive for a longer time, even when the main batteries which supply the motor are completely drained. The cooling effect mentioned in item (iii) above is proposed to cool the Li-ion battery onboard a drone, thus slowing down the thermal degradation of a battery and potentially avoiding thermal runaway. When coupled with an appropriate supercapacitor, the effect mentioned in item (iv) above may allow the drone to keep its main computer and communication equipment alive even longer, thus providing the possibility of sending several distress signals containing the drone's location, to a base station. This may be crucial in recovering the drone, and thus potentially avoiding expenses related to replacing an entire drone.

The remainder of the paper is organized as follows. Section 2 provides an overview of the proposed fuel cell and battery-based energy system. Section 3 provides details of the experimental setup, and displays experimental results. Finally, Section 4 concludes the paper.

\section{System Overview}

Figure 1 shows the overall system setup with the main parts labeled, which includes a drone, a remote controller for manual flight control, and a ground station computer for data logging and visualization. 


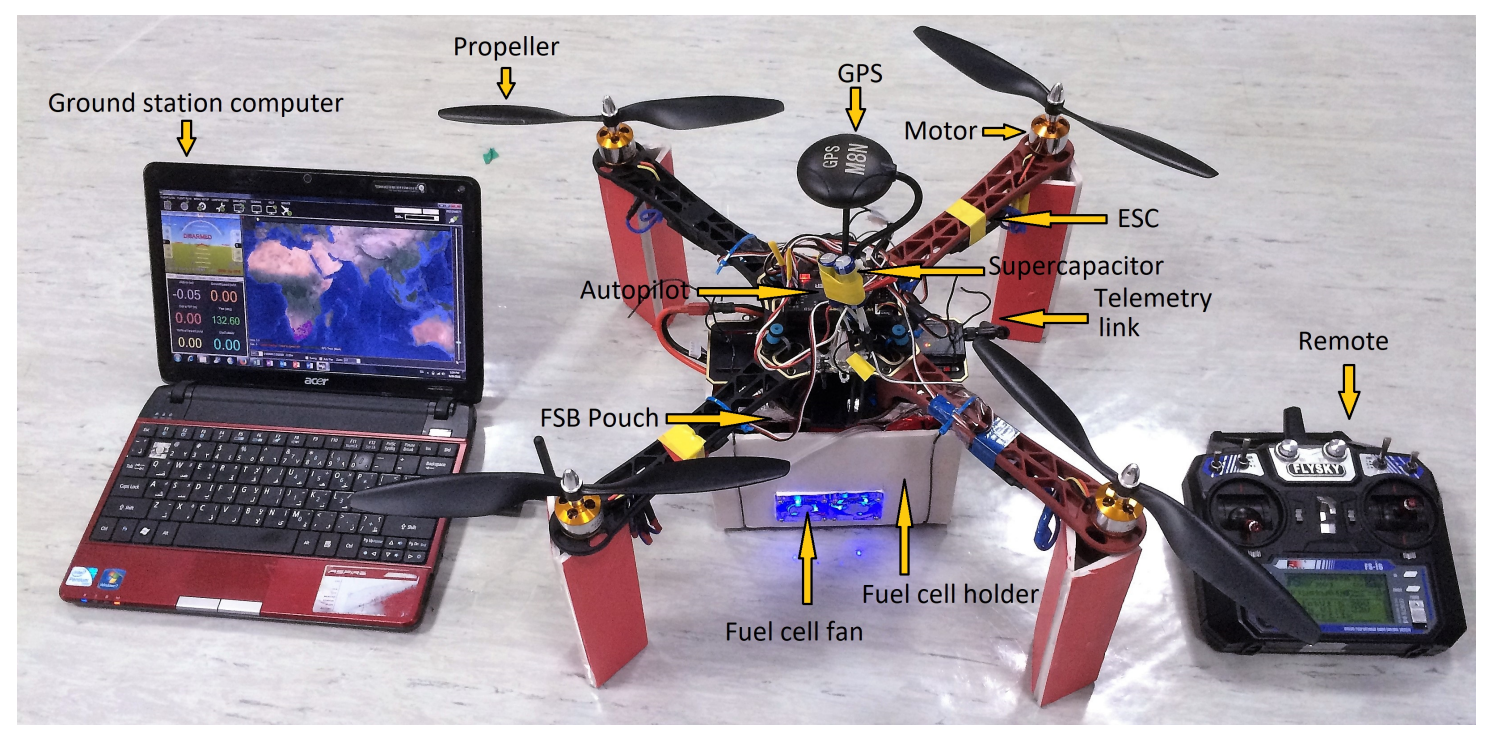

Figure 1. Overall system setup.

\subsection{Hardware}

The drone shown in Figure 1 was assembled using various custom components. The drone comprises four propellers, four motors, four electronic speed controllers (ESCs), the crossarms and baseplate (forming the body of the drone), a telemetry link (transceiver), a remote control radio receiver (not visible in Figure 1), a fuel cell holder, a fuel stick and battery (FSB) pouch which contains the metal hydride fuel stick and a Li-ion battery, supercapacitors, a global positioning system (GPS) module, and the flight computer (or autopilot). As seen in Figure 1, the fuel cell holder box is held by wire ties (black thin wires running vertically). This arrangement was used so that flight tests could be carried out easily, with or without including the fuel cell assembly. Details related to the electrical system configuration when the drone was used with/without the fuel cell and supercapacitor are provided below.

\subsection{Electrical System Schematic without Fuel Cell Stack and Supercapacitor}

As shown in Figure 2, the heart of the quadrotor-based drone is the flight controller, i.e., an Ardupilot Mega (APM) [21]. The APM is loaded with ArduCopter firmware. This flight controller provides autopilot functions which enable the drone to perform missions, like GPS waypoint following and altitude holding. The flight controller also logs data in its flash memory, which is essential for analyzing flights. Also, as seen in Figure 2, the APM is connected to an external GPS unit, enabling positioning. There is also an output port which connects to the ESCs. The ESCs receive pulse width modulated (PWM) signals from the APM and drive the motors according to the received PWM commands, to achieve a desired motor speed. The power supply for the ESCs to drive the motors, is received from a power supply module. The power supply module has two inputs, an onboard DC-DC buck converter module, and several outputs. The inputs to the power supply module are from a battery with a rated voltage of $11.1 \mathrm{~V}$. This approximately $11 \mathrm{~V}$ supply line is passed to the ESCs by the power module, (shown in Figure 2 by the thicker red and black lines. Also, the onboard DC-DC buck converter module provides a secondary output at $5 \mathrm{~V}$ and approximately $3 \mathrm{~A}$ (max). This second output (shown by the thin red and black lines) is used to power the APM and the other peripherals connected to it. The other thin wires from the power module to the APM represent the current and voltage sensing connections, which allow the current and voltage sensors embedded within the power module to measure and record the battery voltage and supplied current. The two other items connected to the APM are the telemetry radio module and the radio receiver for manual control. The $433 \mathrm{Mhz}$ $(100 \mathrm{~mW})$ HopeRF HM-TRP telemetry radio module uses a UART communication interface and 
transmits data at a rate of up to $250 \mathrm{kbps}$. Using this module, the drone's altitude, heading, pitch, battery voltage, current and a few other variables can be monitored via the ground station laptop. To enable manual control of the drone, a FlySky 6 channel $2.4 \mathrm{GHz}$ radio receiver is used, and pairing a FlySky radio transmitter (remote) to it enables control of the thrust, yaw, pitch and roll of the drone manually. In addition, certain switches on the FlySky transmitter allow the drone to be switched into autopilot mode from manual control mode, mid-flight, by configuring the switches appropriately via the Mission Planner software [22].

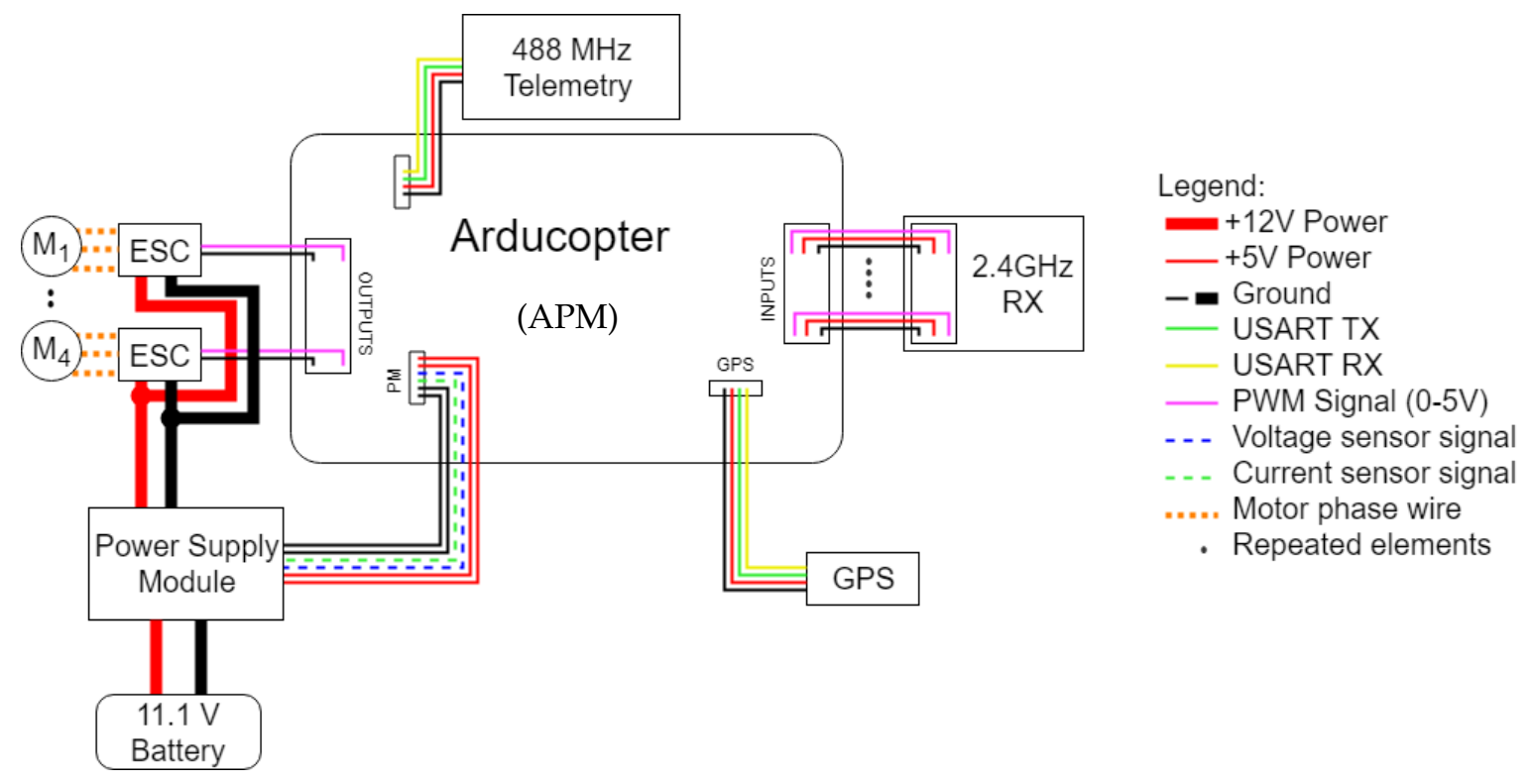

Figure 2. Electrical system schematic without fuel cell stack and supercapacitor.

To provide the required thrust for the quadrotor-based drone to maintain flight, four $1000 \mathrm{kv}$ outrunner brushless motors are used. The $\mathrm{kv}$ rating of the above mentioned motor is a number which provides an approximate idea about the no-load speed expected, when a unit voltage is applied to the motor. The propeller attached to each motor is a Hobbyking Slow Fly $10 \times 4.5$, i.e., it has a 10 inch length and 4.5 inch pitch. The motors are powered by a 3 cell $(11.1 \mathrm{~V}), 3000 \mathrm{mAh}$ lithium polymer battery. Each of these motors can draw a maximum current of $12 \mathrm{~A}$ at the rated supply voltage of $11.1 \mathrm{~V}$ and produce a maximum thrust equivalent to a weight of around $0.7 \mathrm{~kg}$. As mentioned above, the motors are powered by ESCs. The ESCs are rated at $11.1 \mathrm{~V}$ and $30 \mathrm{~A}$. The current rating of the ESCs is selected to be much larger than the motor current rating to enable sudden spikes in the motor current that may occur due to in-flight turbulence, to be handled.

\subsection{Electrical System Schematic with Fuel Cell Stack and Supercapacitor}

The above section provided details about the mode of operation when a battery is used as the sole power source. However, this can cause certain issues, e.g., if there are very violent gusts of wind which require an enormous amount of current from the motors, the battery voltage may momentarily drop, which may cause the flight computer to suffer interruptions, or, in severe cases, restart. Further, because the flight computer, GPS, telemetry and other electronics feed off the same power source as the motors, the flight time of the drone is potentially reduced. So, as shown in Figure 3, a battery is only used to power the motors, and a fuel cell stack is used to power the APM and all electronics connected to the APM. The fuel cell stack used is a Horizon (H-30) proton exchange membrane (PEM) fuel cell stack, rated at $30 \mathrm{~W}, 8.4 \mathrm{~V}$, and 3.6 A. The fuel cell stack is powered by a metal hydride fuel stick. Other details are available from the manufacturer's datasheets for the fuel cell stack, and details about the metal hydride fuel stick are available in Tables 1 and 2. It must be noted that, as these are commercially sold products, all details may not be available because such information may be proprietary. It is also 
worth noting that although Table 2 shows the fuel stick weight to be around $105 \mathrm{~g}$, our measurements of both empty, and fully charged metal hydride fuel sticks showed that their weight is around $92 \mathrm{~g}$. The entire stack consists of 14 individual cells. As shown in Figure 3, the fuel cell stack is connected to a battery eliminator circuit (BEC), which includes a buck converter module, so that the $8.4 \mathrm{~V}$ supply from the fuel cell is converted to the $5 \mathrm{~V}$ level required by the APM. A supercapacitor rated at $5 \mathrm{~V}$, $5 \mathrm{~F}$ is connected in parallel to the output of the BEC. This $5 \mathrm{~V}, 5 \mathrm{~F}$ supercapacitor module is obtained by connecting two $2.5 \mathrm{~V}, 10 \mathrm{~F}$ supercapacitors in series.

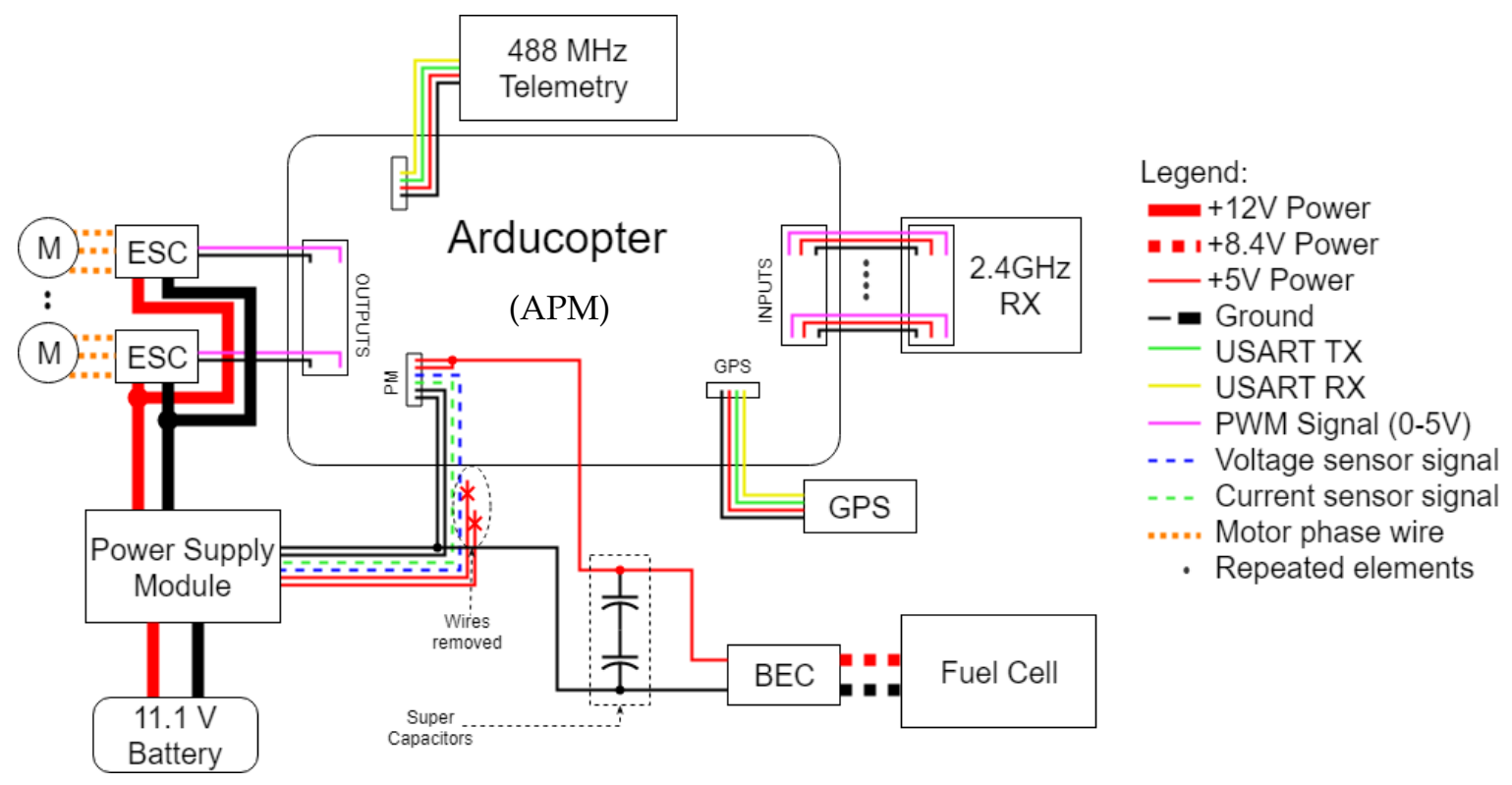

Figure 3. Electrical system schematic with fuel cell stack and supercapacitor.

Table 1. H-30 PEM fuel cell specifications.

\begin{tabular}{cc}
\hline Item & Description \\
\hline Fuel Cell Type & Proton Exchange Membrane (PEM) \\
No. of cells & 14 \\
Rated output power & $30 \mathrm{~W}$ \\
Typical voltage and current output & $8.4 \mathrm{~V}, 3.6 \mathrm{~A}$ \\
Purge valve voltage & $6 \mathrm{~V}$ \\
Controller voltage & $5 \mathrm{~V}$ \\
Reactants & Hydrogen and air \\
Maximum stack temperature & $55^{\circ} \mathrm{C}$ \\
Hydrogen pressure & $0.45-0.55 \mathrm{bar}$ \\
Humidification & Self-humidified \\
Cooling & Air $($ via integrated cooling fan $)$ \\
Dimensions & $8 \mathrm{~cm} \times 4.7 \mathrm{~cm} \times 7.5 \mathrm{~cm}$ \\
Flow rate at maximum output & $0.42 \mathrm{~L} / \mathrm{min}$ \\
Start-up time & $\leq 30 \mathrm{~s}$ \\
Stack efficiency & $40 \%$ at rated power \\
Stack weight & $280 \mathrm{~g}( \pm 30 \mathrm{~g})$ \\
Controller weight & $90 \mathrm{~g}( \pm 10 \mathrm{~g})$ \\
\hline
\end{tabular}


Table 2. Hydrostick Pro metal hydride fuel stick specifications.

\begin{tabular}{cc}
\hline Item & Description \\
\hline Capacity & $10 \mathrm{~L}$ \\
Storage material & AB5 metal hydride \\
Cylinder material & Aluminium \\
Cartridge size & $22 \mathrm{~mm}$ (diameter) $\times 88 \mathrm{~mm}$ (height) \\
Weight & Approximately $105 \mathrm{~g}$ \\
Rated charging pressure & $3 \mathrm{MPa}$ \\
Typical discharging performance & $0.3-0.5 \mathrm{~L} / \mathrm{min}$ \\
Working temperature & $0-55^{\circ} \mathrm{C}$ \\
Service life & 10 years \\
\hline
\end{tabular}

The supercapacitor module is used for the following reasons: (i) The fuel cell operates by using hydrogen from a fuel stick, and oxygen from the air. In the process of generation of electricity, there is some water which routinely collects within the fuel cell unit. This collection of water is detrimental to the operation of the fuel cell, and is periodically removed by a purge controller. The purge cycle lasts for a very short duration (of the order of milliseconds), but during this time period, the fuel cell output voltage drops sharply to a very low value. Such voltage interruptions affect the output of the BEC, as shown by the solid blue curve (thick line with diamond shaped markers) in Figure 4, and thus, interrupt the operation or cause a reboot of the flight controller. So, a filtering capacitor (in this case a supercapacitor) is placed in parallel across the BEC output terminals; the result of this is obvious from Figure 4, where the smoother red curve (thin line with circular markers) does not show any drop in voltage. (ii) Also, the supercapacitor is pre-charged to $5 \mathrm{~V}$ before flight, and if it loses any charge during the purge cycle of the fuel cell, the fuel cell can re-charge the supercapacitor as it supplies the APM. Because the current required by the APM is low (of the order of a few hundred $\mathrm{mA}$ ), a $5 \mathrm{~F}$ supercapacitor at $5 \mathrm{~V}$ can store energy to supply power to the flight computer in case of emergencies where the drone has to make a sudden landing, e.g., if the batteries powering the motor run low. Having the supercapacitor as a last auxiliary power supply when both the fuel stick and battery are exhausted has the potential to increase the amount of time the APM and the communication equipment stays powered on, which would enable the drone to keep sending its position to its home base regularly, and thus, improve the chances of its recovery. Also, note from Figure 4 that the BEC output voltage is slightly above $5 \mathrm{~V}$; this does not cause issues with the supply to the Arducopter APM flight controller because although a $5 \mathrm{~V}$ supply is preferred, the absolute maximum that the flight controller can tolerate is around $6 \mathrm{~V}$.

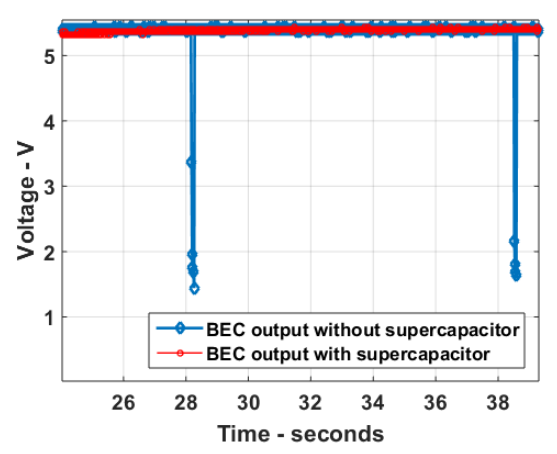

Figure 4. A snapshot of battery eliminator circuit (BEC) output voltage with/without the supercapacitor in parallel across it when the BEC is supplied by the fuel cell stack. 


\subsection{Ground Station Software}

Mission Planner software [22] was used to remotely monitor the flight missions of the quadrotorbased drone. Figure 5 shows a screenshot of the mission planner interface during one such mission. As is visible from Figure 5, a variety of data is accessible live via the telemetry link. This includes altitude, ground speed, battery voltage, battery current, and even the estimated battery capacity remaining. The right-hand-side of Figure 5 shows the drone on a map, whereas the panel on the left-hand-side shows all the information mentioned above. This software interface was used to gather all the data related to the experiments mentioned in Section 3.

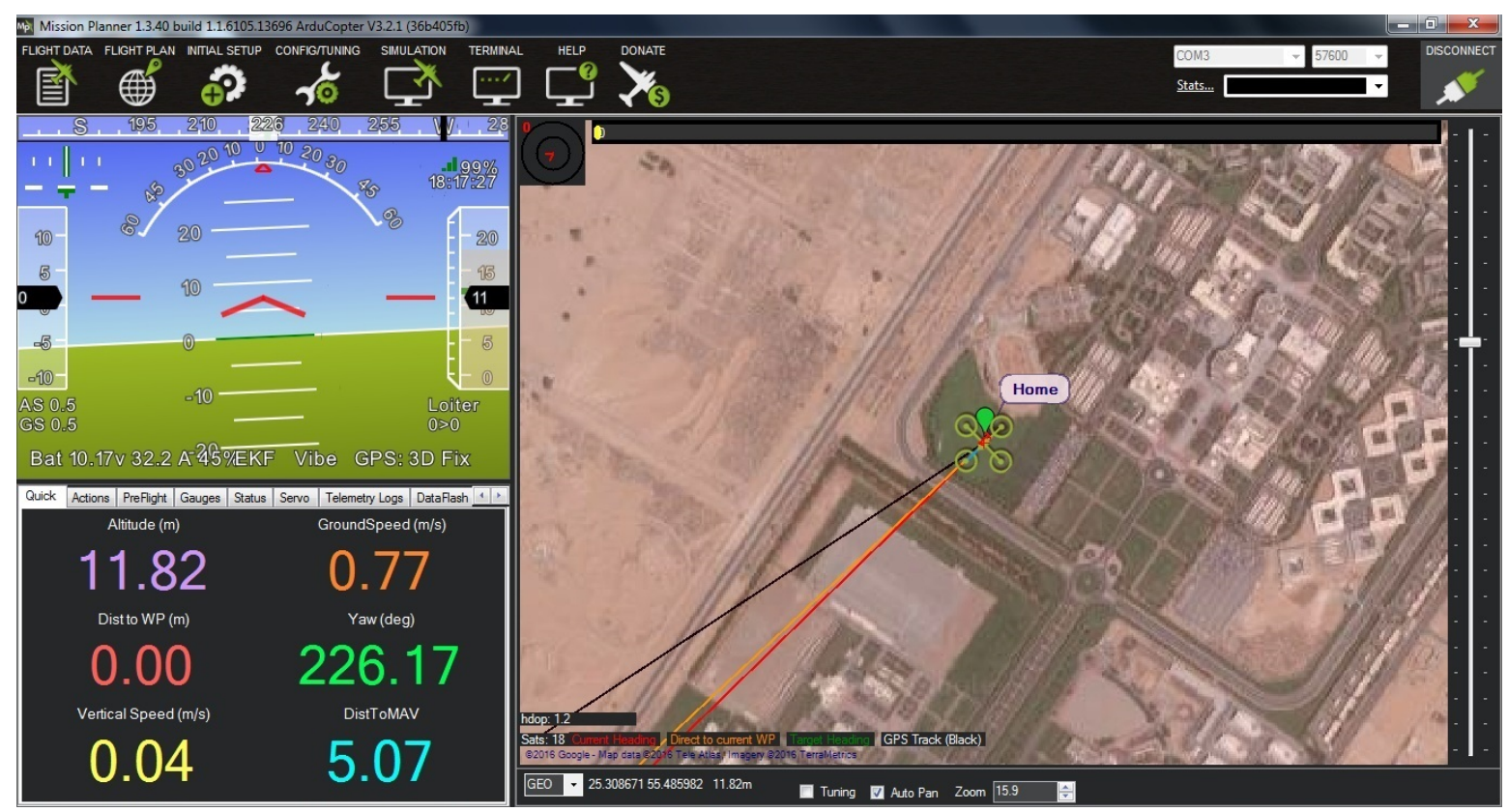

Figure 5. Mission Planner screenshot during flight.

\section{Experiments and Results}

This section details the experimental setup used to demonstrate that a metal hydride fuel stick-based PEM fuel cell can not only be used as a power source to power a flight computer on a drone, but the cooling effect of the fuel stick can be used to cool Li-ion batteries onboard the drone.

\subsection{Experimental Setup}

The experimental modes involved flying the drone in an altitude hold mission, or in a loiter mode at a particular GPS co-ordinate mission for both cases i.e., with or without the fuel cell unit and the solid fuel stick onboard the drone. As shown in Figure 1, the fuel cell holder is a box attached to the bottom of the drone chassis. For experimental runs with only the battery, this fuel cell holder box was removed and also, the fuel stick was removed from the drone. The electrical power circuits for both modes of operation with/without the fuel cell are also shown in Figures 2 and 3. The details of the contents within the fuel cell holder box from Figure 1 are visible in Figure 6.

The white and blue cylindrical object in Figure 6 is the 'Hydrostik Pro' metal hydride fuel stick, the detailed specifications for which are available in Table 2. It is a metal hydride storage system for hydrogen. The top of the fuel stick is connected to a pressure regulator, which is further connected to the hydrogen input tube, which connects the fuel stick to the Horizon H-30 PEM fuel cell stack. Note that once the fuel stick is connected, the fuel cell starts working immediately. The fuel stick can be connected by simply screwing the pressure regulator tightly onto the fuel stick, which starts the flow of hydrogen. The fan on the side of the H-30 fuel cell stack is used to absorb air, and also to maintain the 
internal temperature of the fuel cell stack. A tube is connected to the exhaust port of the fuel cell stack; this water exhaust tube passes through the purge valve. The purge valve is connected to the purge cycle controller, which is seen in black behind the fuel cell stack, and it controls the opening and closing of the purge valve for the removal of accumulated water vapor within the stack. The two electrical output wires from the H-30 fuel cell stack are connected to the BEC; the details of the electrical systems are available in Figures 2 and 3. Also, a battery used is shown in the bottom-left corner of Figure 6. For details related to the operation of the parts of the fuel cell stack shown in Figure 6, readers are directed to [23].

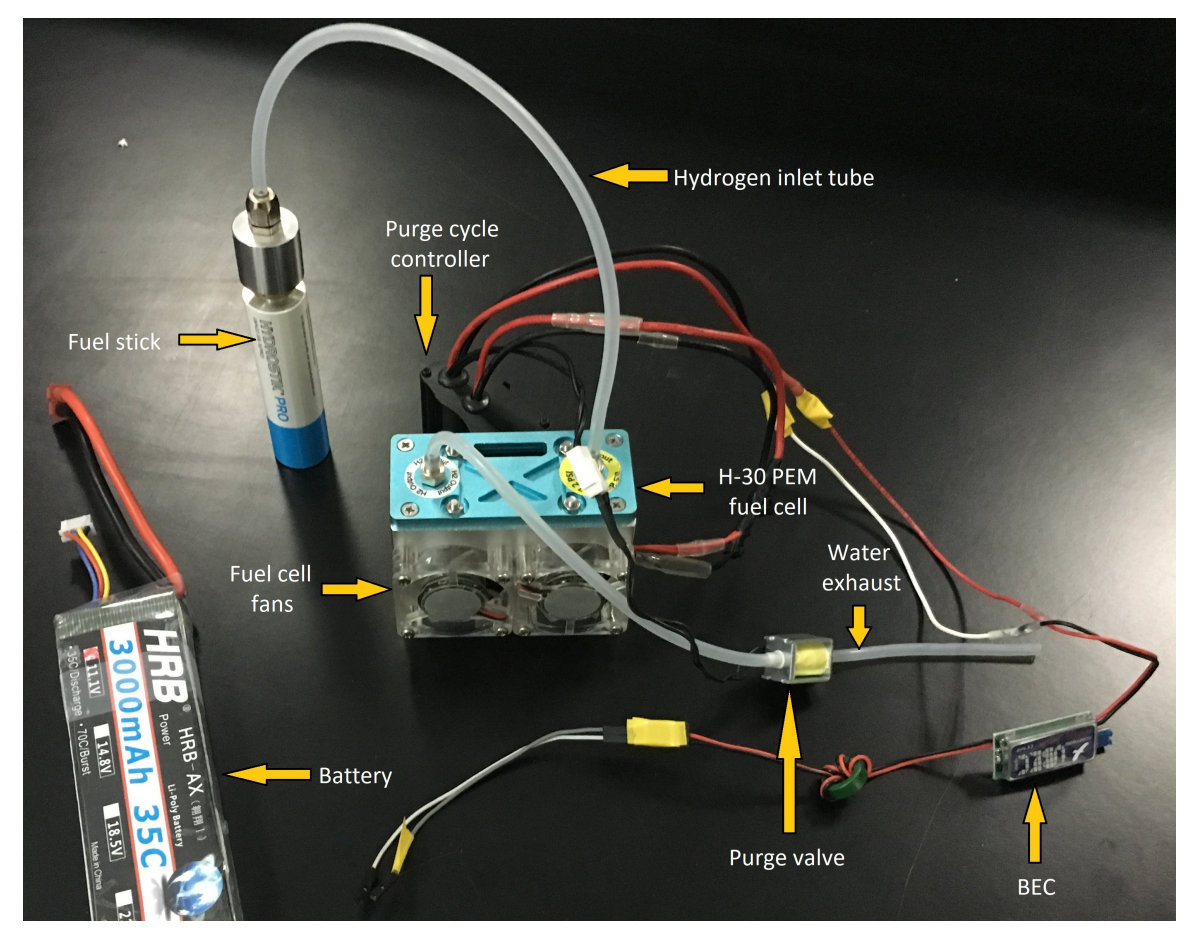

Figure 6. Components of the drone power supply and battery cooling system.

In Section 3.2, it is shown that the fuel cell stick shown in Figure 6 cools as it supplies hydrogen to the fuel cell stack. The prototype battery cooling assembly used to take advantage of this cooling effect is shown in the left half of Figure 7. The fuel cell stick and battery are enclosed in an all around jacket of aluminium foil; this is labeled in Figure 1 as the FSB pouch. This is done so that the cooler fuel stick could absorb heat from all over the surface of the battery. This prototype battery cooling assembly is then strapped to the bottom of the drone chassis, as shown in the right half of Figure 7. The prototype battery cooling assembly shown in Figure 6 is not necessarily an optimized design; however, it is an initial prototype. Optimization of the design for the cooling assembly is beyond the current scope of the paper and will be handled in future efforts.

For the experiments where the fuel cell was not used, the aluminium cooling jacket and the fuel stick were removed, the fuel cell holder box and its components were not attached to the drone chassis, and the battery was strapped into the bottom of the drone by itself. At this point it is worth making a comparison of the drone weight with/without the fuel cell stack and required peripherals; these details are shown in Table 3. As seen in Table 3, without the fuel cell, when the drone was powered by the battery alone, it weighed $1.2 \mathrm{~kg}$. With the fuel cell and all associated components, the drone weighed approximately $1.75 \mathrm{Kg}$. Recall from Section 2.1 that each motor provides a thrust equivalent to a weight of $0.7 \mathrm{~kg}$, so even after using the fuel cell stack and associated peripherals on board, the drone should easily be able to lift at least an additional payload of $500 \mathrm{~g}$. 

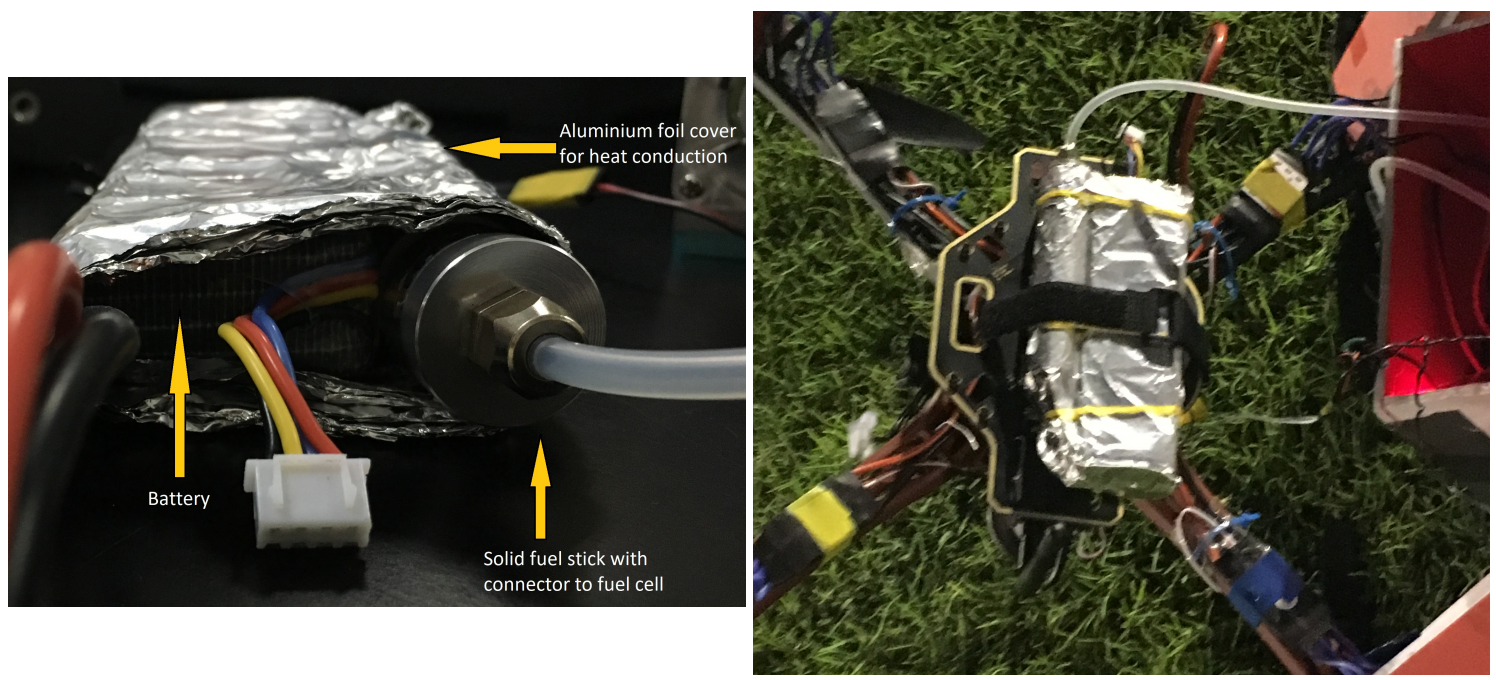

Figure 7. Left: A prototype battery cooling assembly via contact with a solid fuel stick. Right: A view of the prototype cooling assembly mounted on the bottom of the drone.

Table 3. Weights of drone components.

\begin{tabular}{cccc}
\hline Item & $\begin{array}{c}\text { Drone } \\
\text { Chassis with } \\
\text { Battery }\end{array}$ & $\begin{array}{c}\text { Fuel Cell Holder Box with all } \\
\text { Required Components (Including } \\
\text { Fuel Stick and Pressure Regulator) }\end{array}$ & $\begin{array}{c}\text { Prototype } \\
\text { Aluminium Foil } \\
\text { Cooling Jacket }\end{array}$ \\
\hline Weight $(\mathrm{g})$ & 1200 & 525.46 & 24.552 \\
\hline
\end{tabular}

\subsection{Experimental Results}

This section presents the results of the experiments conducted using the setup described in the section above.

\subsubsection{Cooling Effect Produced by Fuel Cells}

At first, the results showing the cooling effect of the solid fuel stick when it supplies the fuel cell stack are presented. This is shown in Figure 8 where the fuel cell stick is seen to decrease from its initial temperature of $33^{\circ} \mathrm{C}$ to $23.14^{\circ} \mathrm{C}$ in around $9 \mathrm{~min}$. Several such tests have been conducted in the absence of any external source of heat which can raise the temperature of the fuel stick. In every case, the result observed is that regardless of the initial temperature within a range of $20-35^{\circ} \mathrm{C}$, the final temperature of the fuel stick is about $7-10^{\circ} \mathrm{C}$ lower than its initial temperature, when measured around 9-10 min from the initial time at which the fuel stick started supplying the stack and when hydrogen is being supplied at a constant rate (as needed by the $\mathrm{H}-30$ fuel cell stack used in this paper). Figure 9 shows another set of results, where the fuel stick is seen to cool from an initial temperature of around $26^{\circ} \mathrm{C}$, to around $6{ }^{\circ} \mathrm{C}$. It must be noted that such a large decline in temperature was observed when the fuel stick supplied the fuel cell for a longer duration (about $20 \mathrm{~min}$ or more) without any external heat source being in contact with the fuel stick, and also when the purge connections were initially left open, thus resulting in a large initial burst of hydrogen being released. The results in Figure $9 \mathrm{a}, \mathrm{b}$ are provided to show that metal hydride fuel sticks have substantial potential to be used in applications which need cooling. The temperature decrease of metal hydride fuel sticks (cartridges) has been well documented [24], and it is due to the fact that the process of 'charging' or absorption of hydrogen in a metal hydride fuel stick is exothermic (releases heat), where as the reverse process, i.e., 'discharging' or release of hydrogen is endothermic (absorbs heat). Thus, motivated by the above observation, we present the results of the use of the fuel stick to cool a Li-ion battery onboard a drone while in flight. Please note that all temperature measurements were verified by at least one of two 
thermal imaging devices and an infrared thermometer. Thermal imaging device 1 automatically plotted plus ' + ' signs at the center of the image and at the points corresponding to the lowest and highest temperatures. The ' + ' corresponding to the highest temperature is shown in red, but the color of the plus sign is only used to signify that it is the hottest point; the temperature scale on the right-hand-side of each of the figures provides a better idea of the actual temperature at a point. Thermal imaging device 2 produces an image of a circular mark with crosshairs superimposed on the thermal image. All devices used have an accuracy of $\pm 2 \%$ of the readings, so it was possible to reliably measure the temperatures. Also, experiments were conducted over a series of days, and some results from thermal imaging device 2 acquired towards the end of the series of experiments are shown, because it was observed that the visual quality of the images produced by thermal imaging device 2 was better than those obtained by thermal imaging device 1 .

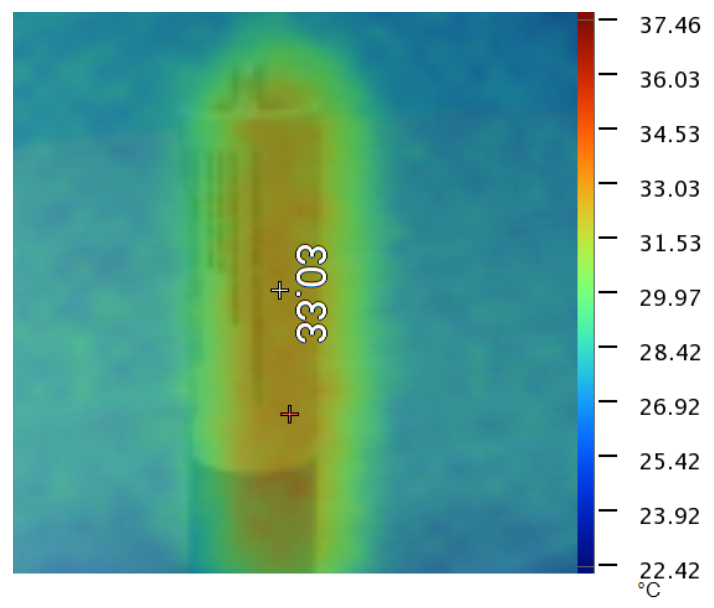

(a)

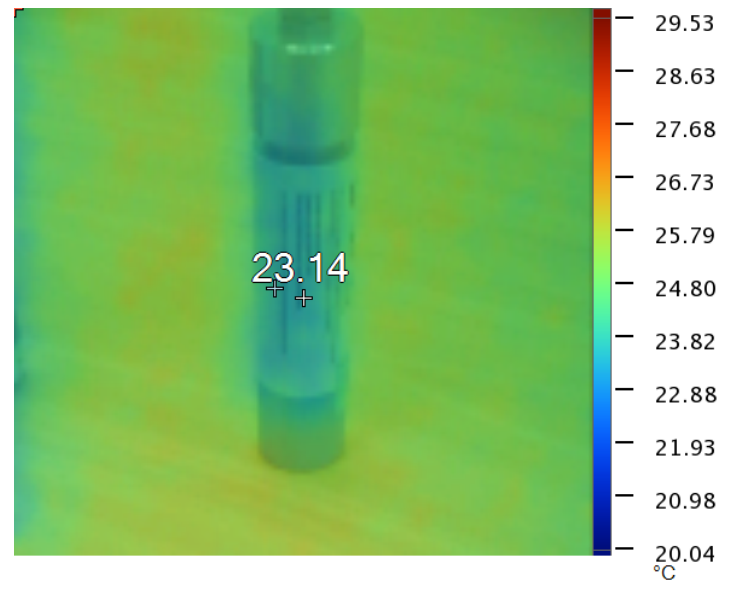

(b)

Figure 8. (a) Temperature of the fuel stick before connecting to fuel cell stack; (b) temperature of fuel stick after being connected to fuel cell stack for about ten minutes. Fuel stick temperature drop test 1 - captured by thermal imaging device 1 .

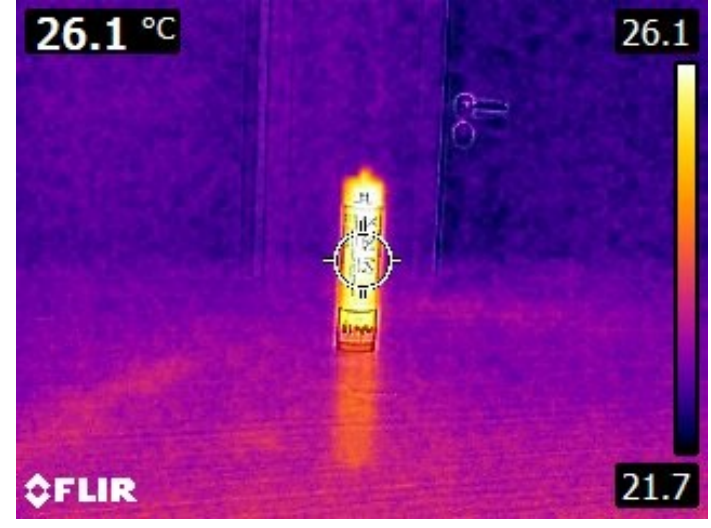

(a)

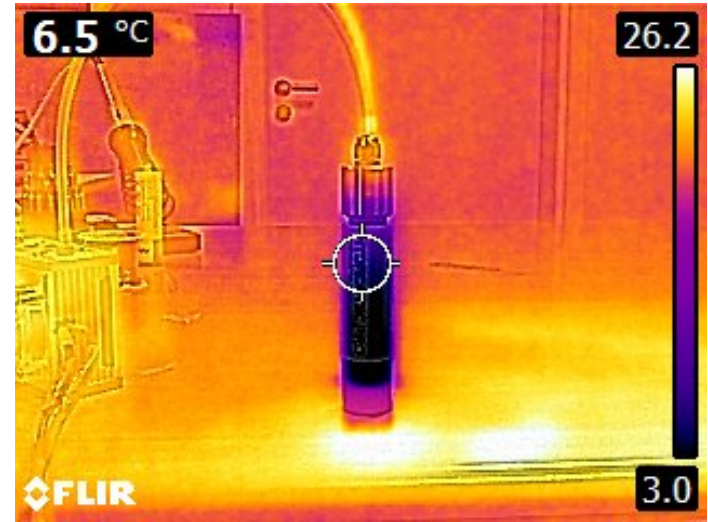

(b)

Figure 9. (a) Temperature of fuel stick before connecting to the fuel cell stack.; (b) temperature of fuel stick after connection to the fuel cell stack for an extended period ( $\sim 20 \mathrm{~min})$, with an initial sudden release of hydrogen from the fuel stick. Fuel stick temperature drop test 2-captured by thermal imaging device 2 . 


\subsubsection{Results of Cooling Batteries Onoard Drones with/without a Fuel Stick}

This subsection provides the results that compare the temperatures of uncooled batteries and ones that are cooled by an onboard fuel cell stack and a fuel stick. Figure 10 shows the results of a drone flight (Flight test 1 ) carried out with the drone powered entirely by a battery. The $3000 \mathrm{mAh}$ battery used provided a flight duration of around $6 \mathrm{~min}$, on average. It is to be noted that on all days during which flight tests were conducted (with or without the fuel cell stack), there were 4-6 mph winds. The left half of Figure 10 shows the initial temperature of the battery pack. During temperature measurements, the battery was laid on a piece of paper, so the grass below did not affect its temperature. As seen in the left half of Figure 10, the battery surface was initially at a temperature of around $30.11^{\circ} \mathrm{C}$. The right half of Figure 10 shows the battery laid on a piece of paper immediately after the drone landed. The surface temperature observed at the center at this point was $52.63^{\circ} \mathrm{C}$, with the highest surface temperature being around $53{ }^{\circ} \mathrm{C}$.

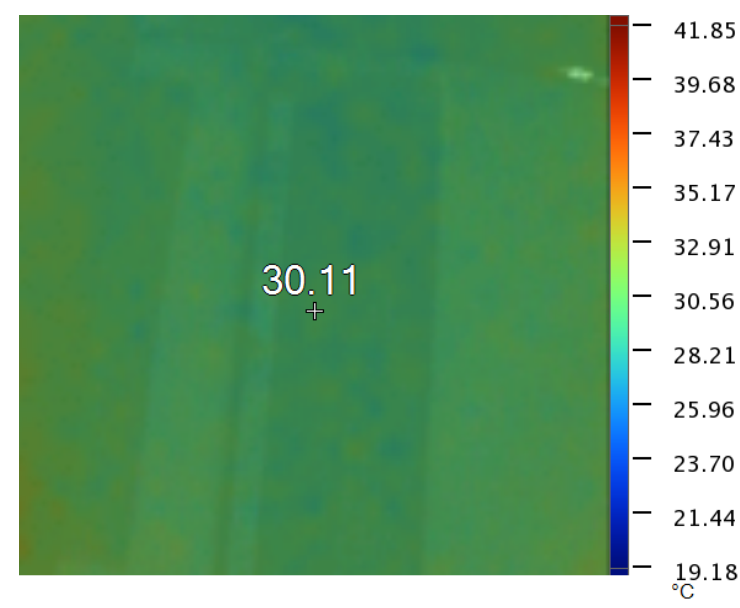

(a)

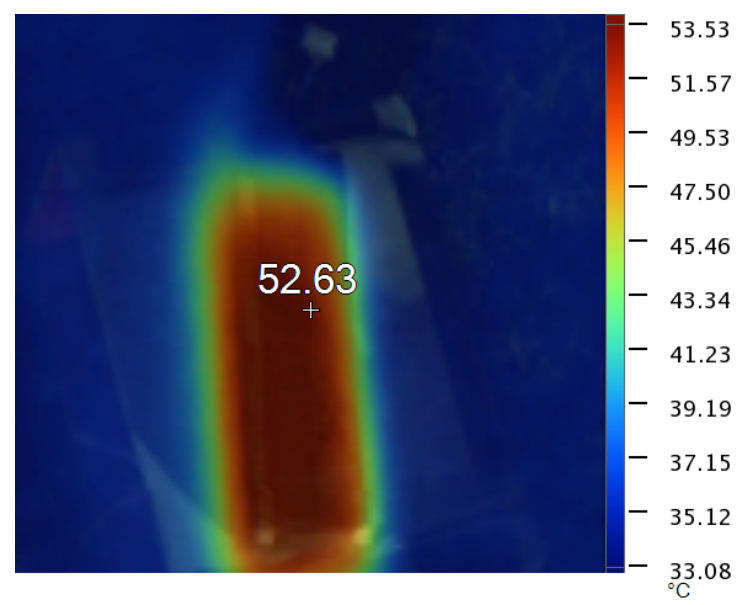

(b)

Figure 10. (a) Temperature of battery before flight; (b) temperature of battery after flight. Flight test 1 -increase in battery temperature without any cooling, captured by thermal imaging device 1 .

Figure 11 shows the results of a drone flight carried out with the drone powered by a battery and a fuel cell stack supercapacitor unit, as shown in Figure 3 (flight test two). The drone was attached to the fuel cell holder containing the fuel cell components and the aluminium jacket with the fuel cell stick and the battery, as shown in Figure 7. The left half of Figure 11 shows the initial temperature of the battery pack. The battery surface was initially at a temperature of around $30.33^{\circ} \mathrm{C}$. The right half of Figure 11 shows the battery laid on a piece of paper immediately after the drone landed. The surface temperature observed at the center at this instant was $48.27^{\circ} \mathrm{C}$, with the highest surface temperature being around $48^{\circ} \mathrm{C}$. This shows that just by using the fuel cell stick with the aluminium jacket for cooling, the battery temperature reduces by around $5{ }^{\circ} \mathrm{C}$.

Also, Figure 12 presents details related to the two flight tests described above. It must be noted that both missions which produced the results in Figures 10 and 11, were altitude hold missions, with the drone required to hold altitude at $15 \mathrm{~m}$. From the different curves shown in Figure 12, it can be concluded that with the fuel cell handling all the power requirements for the flight controller, telemetry and GPS, and the battery supplying only the motors, there was a gain of around half a minute of flight time compared to the case where a single battery was used to power all electronics and the motors.

Several of the previously described tests were carried out with batteries of different capacities from different manufacturers to verify the observations reported above. Table 4 shows the results of these tests. Every odd numbered test in Table 4 represents a test where the drone was powered solely by the battery. Every even numbered test in Table 4 represents a test where the drone was 
powered by a battery, fuel cell stack, supercapacitor, and the battery onboard the drone was cooled using the onboard metal hydride fuel stick and the prototype cooling assembly developed in this work. Tests 1, 2 were performed with a $3000 \mathrm{mAh}$ battery. Tests 3 to 6 were performed with a $2700 \mathrm{mAh}$ battery and tests 7,8 were performed with a $2500 \mathrm{mAh}$ battery. The fourth column in Table 4 shows the difference between the temperature of a battery after no onboard cooling, and the battery temperature measured after a flight with fuel stick based onboard cooling. The average temperature decrease across all tests ( 1 to 8$)$ was $5.19^{\circ} \mathrm{C}$ with a standard deviation of 1.712 . For the gain in flight time computations, the flight times were recorded for purely battery powered drone flights, and drone flights powered by a battery, fuel cell stack, and supercapacitor. The differences between these flight times are shown in the last column of Table 4, and these results show that the mean flight time gained by the use of a fuel cell stack and supercapacitor along with the onboard battery was $26.8 \mathrm{~s}$ with a standard deviation of 11.09. Please note that for flight time gain calculations, only the data for tests 1 to 6 is used because tests 7 and 8 were both interrupted halfway by severe gusts of winds, forcing emergency landings. Figures $13 a, b$ show the temperatures of a battery after the drone landed in flight tests 5 and 6 , respectively. As seen in Figure 13b, the temperature of the battery was lower than the temperature of the battery in Figure 13a. This can also be verified by noticing that a larger portion of the battery surface in Figure 13a appears to be closer to 'white' in color (i.e., higher temperature) compared to the battery surface in Figure 13b. Also Figure 14a,b provide pictures of the fuel stick temperature before take-off and after landing, respectively, for flight test 6 . The cooling effect of the fuel stick is very clearly observed in this case, because despite managing to cool the battery by around $4.6^{\circ} \mathrm{C}$ (i.e., absorbing heat) as seen in Table 4 , the fuel stick surface temperature after landing appeared to be approximately the same temperature (around $31^{\circ} \mathrm{C}$ ) as before take-off.

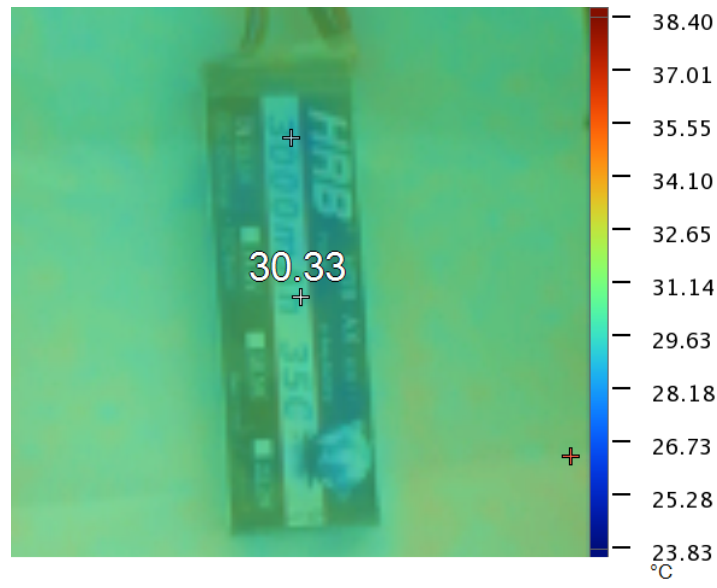

(a)

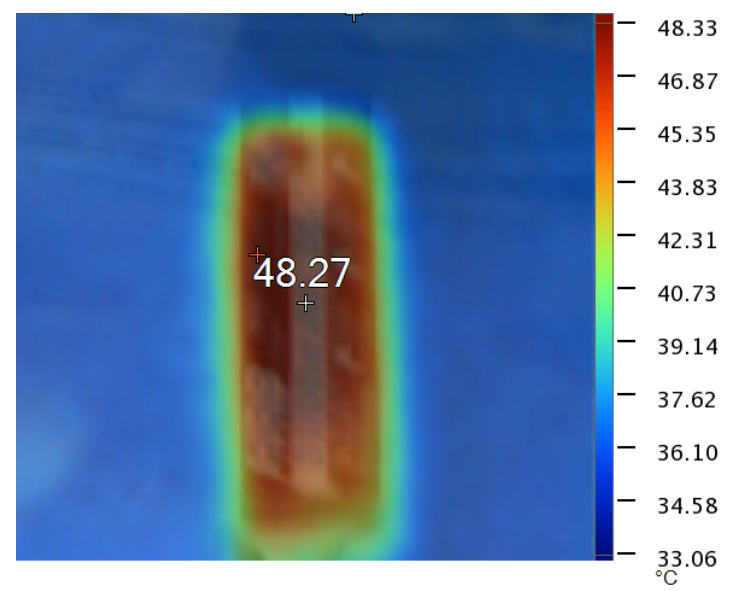

(b)

Figure 11. (a) Temperature of battery before flight; (b) temperature of battery after flight. Flight test 2-increase in battery temperature (cooled by contact with fuel stick, captured by thermal imaging device 1.)

Further it was also observed that, even after the drone had landed in the above tests, and the battery and fuel cell stick were completely exhausted, the use of the supercapacitor allowed the flight computer to stay online for around five minutes. Thus, the proposed system not only helps to cool batteries, but as a side-effect, also enhances flight time a little, and allows the flight computer to stay online longer, all of which are critically important in retrieving a drone in case it makes an emergency landing due to unavoidable situations like a battery running out of power. Note that the $26.8 \mathrm{~s}$ (on an average) of flight time gained may seem small, but this is gained with the use of a $30 \mathrm{~W}$ fuel cell unit with a small capacity fuel stick. These results could possibly be enhanced much further if better capacity fuel sticks were used. Also, the fuel cell stack and peripherals used in these experiments cost 
about 1500-2000 USD, whereas even entry level professional quality fuel cell stacks for flying drones can cost several tens of thousands of USD. Also, as seen from the altitude plots in Figure 12c, Flight tests 1 and 2 with the fuel cell experienced turbulence causing the altitude to fluctuate; this can be verified by looking at the roll plots in Figure 12b, which show that the drone was encountering stronger winds during the test with the fuel cell compared to the test without the fuel cell. In contrast, relatively calmer conditions prevailed during tests 5 and 6 and the flight times increased. Thus, the above observed gain in flight time may be more pronounced in calmer weather conditions.

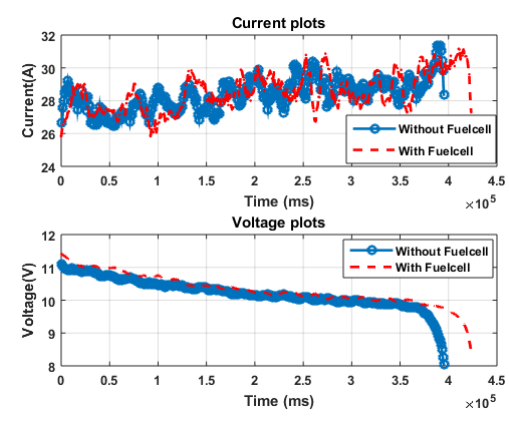

(a) Battery current and voltages.

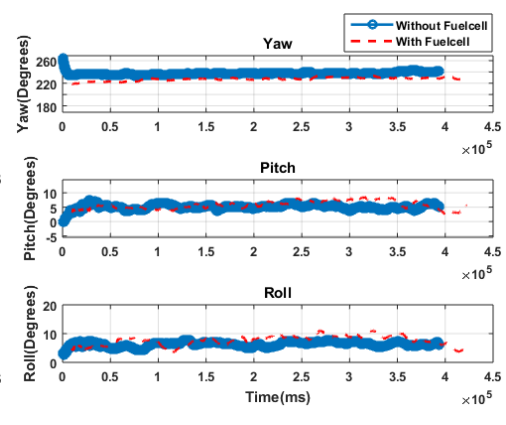

(b) Roll, pitch and yaw.

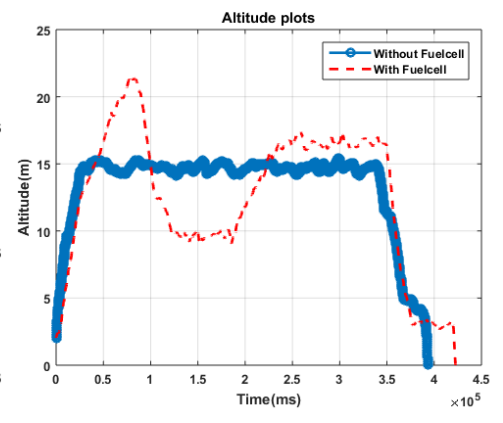

(c) Altitude.

Figure 12. Flight test 1 -flight parameters, with and without fuel cell.

Table 4. Summary of various tests conducted with batteries of various capacities, from different manufacturers.

\begin{tabular}{|c|c|c|c|c|c|}
\hline \multirow{2}{*}{$\begin{array}{l}\text { Flight } \\
\text { Test } \\
\text { Name }\end{array}$} & \multicolumn{2}{|c|}{ Battery Temperature } & \multirow{2}{*}{$\begin{array}{c}\Delta T\left({ }^{\circ} \mathrm{C}\right)=B_{2} \text { Test }_{K}-B_{2} \text { Test }_{K+1}, K \geq 1 \\
\text { (Decrease in Battery Temperature } \\
\text { Using the Fuel Stick) }\end{array}$} & \multirow{2}{*}{$\begin{array}{c}\text { Flight } \\
\text { Time } \\
\text { (minutes) }\end{array}$} & \multirow{2}{*}{$\begin{array}{c}\text { Flight } \\
\text { Time Gained } \\
\text { (seconds) }\end{array}$} \\
\hline & $\begin{array}{c}\text { Takeoff } \\
B_{1}{ }^{\circ} \mathrm{C}\end{array}$ & $\begin{array}{c}\text { Landing } \\
\mathrm{B}_{2}{ }^{\circ} \mathrm{C}\end{array}$ & & & \\
\hline 1 & 30.11 & 52.63 & $\mathrm{~N} / \mathrm{A}$ & 6.58 & $\mathrm{~N} / \mathrm{A}$ \\
\hline 2 & 30.33 & 48.27 & 4.36 & 7.06 & 28.8 \\
\hline 3 & 24.1 & 45.9 & $\mathrm{~N} / \mathrm{A}$ & 6.44 & $\mathrm{~N} / \mathrm{A}$ \\
\hline 4 & 26.9 & 37.8 & 8.1 & 6.61 & 10.2 \\
\hline 5 & 23.4 & 48.6 & $\mathrm{~N} / \mathrm{A}$ & 5.62 & $\mathrm{~N} / \mathrm{A}$ \\
\hline 6 & 28 & 44.0 & 4.6 & 6.31 & 41.4 \\
\hline 7 & 29.2 & 46.4 & $\mathrm{~N} / \mathrm{A}$ & $\mathrm{N} / \mathrm{A}$ & $\mathrm{N} / \mathrm{A}$ \\
\hline 8 & 34 & 42.7 & 3.7 & $\mathrm{~N} / \mathrm{A}$ & $\mathrm{N} / \mathrm{A}$ \\
\hline
\end{tabular}

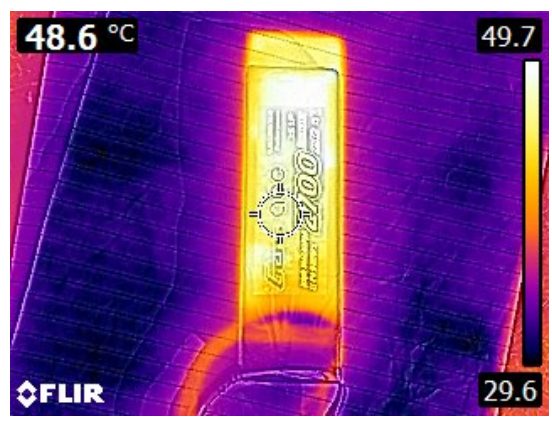

(a)

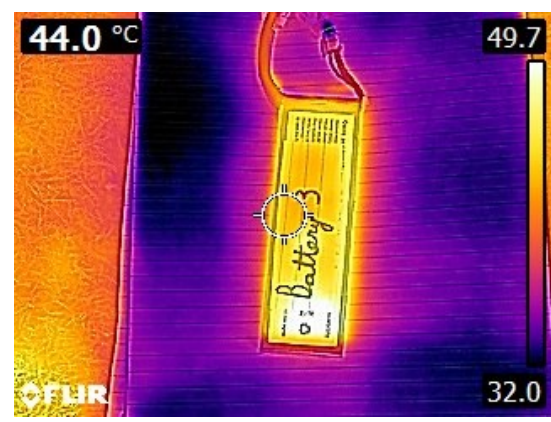

(b)

Figure 13. (a) Flight test 5-temperature of battery without fuel stick-based cooling; (b) Flight test 6 -temperature of battery with fuel stick-based cooling. Flight tests 5 and 6-decrease in battery temperature via fuel stick-based cooling. Images captured by thermal imaging device 2 . 


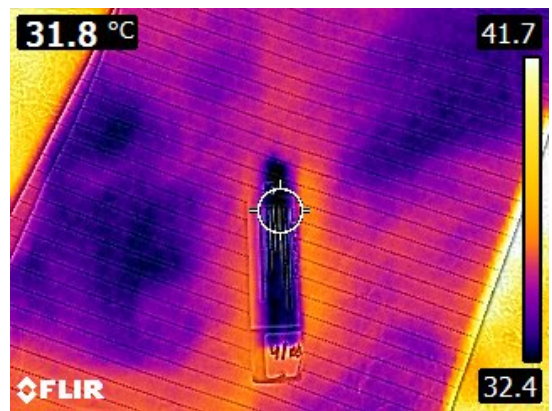

(a)

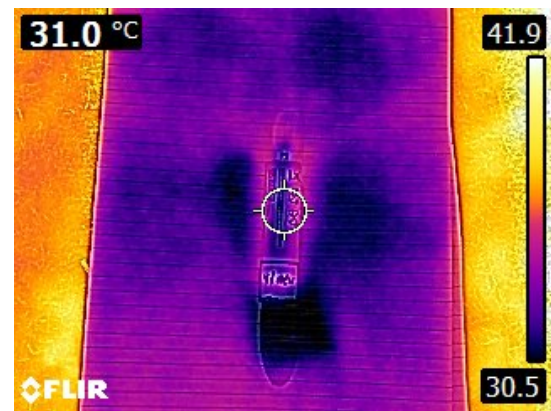

(b)

Figure 14. (a) Flight test 6-temperature of fuel stick before take-off; (b) Flight test 6-temperature of fuel stick after landing. Flight test 6 -fuel stick temperature profiles. Images captured by thermal imaging device 2 .

\section{Conclusions}

In conclusion, this work has presented a novel method involving the use of a small capacity and relatively less expensive fuel cell onboard a drone to cool Li-ion batteries. Temperature rise in batteries is known to cause battery degradation, eventually leading to thermal runaway and explosions. Thus, battery cooling is essential. However, drones are starved for weight, and so mounting an additional cooling system which draws power from a drone's battery, can shorten its flight duration. Thus, this work used a power source (a PEM fuel cell stack), which, when powered by a solid fuel stick, offered dual benefits, i.e., primarily it showed a decrease in battery temperature, and as a side effect, it elongated the flight time a little compared to the case that used only a battery. Further, the above results were verified across several different capacity batteries from different manufacturers.

\section{Future Work}

The work above opens doors to several possibilities for future research. The cooling system enclosure design can be optimized both with respect to thermal and mechanical efficiency. Different options for an onboard fuel cell, and a hydrogen fuel stick, can be tried to find a combination that offers the most benefits, i.e., longer flight time, less add-on weight, and largest cooling effect. Enhancing flight time, while maintaining optimal battery temperature so that thermal failures of batteries and battery degradation can be reduced, is a very challenging and important direction for research. This is because it can definitely help future generations of delivery drones by reducing their overall operating costs related to frequent replacement of batteries due to thermal failure. Further, the cooling effect reported in this paper can also be applied to other applications where overheating may be an issue.

Author Contributions: S.M. conceived the idea, the system, and the experiments and also supervised the experiments. S.M. mainly handled the writing of this manuscript with some initial assistance from M.S. and S.F. Further, S.F. and M.S. designed the system, and performed initial experiments, D.W. performed a later batch of experiments and analyzed the experimental data.

Acknowledgments: Parts of this work were funded by a seed grant provided by the department of electrical engineering at the American University of Sharjah, UAE. The authors also acknowledge Usman Butt for help with a field test.

Conflicts of Interest: The authors declare no conflict of interest. 


\section{References}

1. Ackerman, E.; Strickland, E. Medical delivery drones take flight in east Africa. IEEE Spectr. 2018, 55, 34-35. [CrossRef]

2. Chung, A.Y.; Lee, J.Y.; Kim, H. Autonomous Mission Completion System for Disconnected Delivery Drones in Urban Area. In Proceedings of the 2017 IEEE International Conference on Robotics and Biomimetics (ROBIO), Macau, China, 5-8 December 2017; pp. 56-61.

3. Lim, J.; Jung, H. Drone Delivery Scheduling Simulations Focusing on Charging Speed, Weight and Battery Capacity: Case of Remote Islands in South Korea. In Proceedings of the Winter Simulation Conference (WSC), Las Vegas, NV, USA, 3-6 December 2017; pp. 4550-4551.

4. Park, S.; Zhang, L.; Chakraborty, S. Battery Assignment and Scheduling for Drone Delivery Businesses. In Proceedings of the IEEE/ACM International Symposium on Low Power Electronics and Design (ISLPED), Taipei, Taiwan, 24-26 July 2017; pp. 1-6.

5. Dorling, K.; Heinrichs, J.; Messier, G.G.; Magierowski, S. Vehicle Routing Problems for Drone Delivery. IEEE Trans. Syst. Man Cybern. Syst. 2017, 47, 70-85. [CrossRef]

6. Gonzalez, T.; David, J.; Fung, W.K. A Pilot Study on Aeronautical Surveillance System for Drone Delivery Using Heterogeneous Software Defined Radio Framework. In Proceedings of the IEEE International Conference on Real-time Computing and Robotics (RCAR), Okinawa, Japan, 14-18 July 2017; pp. 499-504.

7. Linden, D.; Reddy, T.B. Handbook of Batteries, 3rd ed.; McGraw-Hill: New York, NY, USA, 2002.

8. Saw, L.; Tay, A.A.O.; Zhang, L.W. Thermal Management of Lithium-Ion Battery Pack with Liquid Cooling. In Proceedings of the 31st IEEE Thermal Measurement, Modeling \& Management Symposium (SEMI-THERM), San Jose, CA, USA, 15-19 March 2015; pp. 298-302.

9. Madani, S.; Schaltz, E.; Knudsen Kær, S. Review of Parameter Determination for Thermal Modeling of Lithium Ion Batteries. Batteries 2018, 4, 20. [CrossRef]

10. De Hoog, J.; Jaguemont, J.; Abdel-Monem, M.; Van Den Bossche, P.; Van Mierlo, J.; Omar, N. Combining an Electrothermal and Impedance Aging Model to Investigate Thermal Degradation Caused by Fast Charging. Energies 2018, 11, 804. [CrossRef]

11. Koch, S.; Birke, K.; Kuhn, R. Fast Thermal Runaway Detection for Lithium-Ion Cells in Large Scale Traction Batteries. Batteries 2018, 4, 16. [CrossRef]

12. Bhide, S.; Shim, T. Novel Predictive Electric Li-Ion Battery Model Incorporating Thermal and Rate Factor Effects. IEEE Trans. Veh. Technol. 2011, 60, 819-829. [CrossRef]

13. Xiao, Y. Model-Based Virtual Thermal Sensors for Lithium-Ion Battery in EV Applications. IEEE Trans. Ind. Electron. 2015, 62, 3112-3122. [CrossRef]

14. Saw, L.; Ye, Y.; Tay, A. Electro-thermal characterization of Lithium Iron Phosphate cell with equivalent circuit modeling. Energy Convers. Manag. 2014, 87, 367-377. [CrossRef]

15. Ali, D.; Mukhopadhyay, S.; Rehman, H.; Khurram, A. UAS based Li-ion battery model parameters estimation. Control Eng. Pract. 2017, 66, 126-145. [CrossRef]

16. Klein, R.; Chaturvedi, N.A.; Christensen, J.; Ahmed, J.; Findeisen, R.; Kojic, A. Electrochemical Model Based Observer Design for a Lithium-Ion Battery. IEEE Trans. Control Syst. Technol. 2013, 21, 289-301. [CrossRef]

17. Mukhopadhyay, S.; Zhang, F. A high-gain adaptive observer for detecting Li-ion battery terminal voltage collapse. Automatica 2014, 50, 896-902. [CrossRef]

18. Belmonte, N.; Staulo, S.; Fiorot, S.; Luetto, C.; Rizzi, P.; Baricco, M. Fuel cell powered octocopter for inspection of mobile cranes: Design, cost analysis and environmental impacts. Appl. Energy 2018, 215, 556-565. [CrossRef]

19. Lee, B.; Kwon, S.; Park, P.; Kim, K. Active power management system for an unmanned aerial vehicle powered by solar cells, a fuel cell, and batteries. IEEE Trans. Aerosp. Electron. Syst. 2014, 50, 3167-3177. [CrossRef]

20. Lindahl, P.; Moog, E.; Shaw, S.R. Simulation, Design, and Validation of an UAV SOFC Propulsion System. IEEE Trans. Aerosp. Electron. Syst. 2012, 48, 2582-2593. [CrossRef]

21. ArduPilot Mega, the Open Source Autopilot. Available online: https://www.ardupilot.co.uk (accessed on 5 June 2018).

22. Mission Planner. Available online: http://ardupilot.org/planner/docs/mission-planner-overview.html (accessed on 5 June 2018). 
23. Horizon Educational. Available online: http://www.horizoneducational.com (accessed on 5 June 2018).

24. Vasiliev, L.; Vasiliev, L., Jr. Mini-Micro Fuel Cells: Fundamentals and Applications; Chapter-Heat Transfer Enhancement in Confined Spaces of Mini-Micro Fuel Cells; Kakaç, S., Pramuanjaroenkij, A., Vasiliev, L., Eds.; Springer: Berlin/Heidelberg, Germany, 2008. 